\title{
MATERIAL PLANNING AND SUPPLY MANAGEMENT SYSTEM FOR PRODUCTION INDUSTRIES
}

\author{
Nithin S K, Likith Naik S, Rahul B, Padmaja S K \\ BE Students, Department of Information Science and Engineering \\ Dayananda Sagar Academy of Technology and Management, Bangalore, Karnataka India

\section{Dr. Sumithra Devi K} \\ Professor and Head Department of Information science and Engineering \\ Dayananda Sagar Academy of Technology and Management, Bangalore, Karnataka India
}

\begin{abstract}
In production network the executives (SCM), two subjects have picked up significance in the course of the most recent years. From one viewpoint, reasonable SCM (SSCM) has become progressively important and numerous productions have contributed to the subject. Then again, data innovation (IT) is being continuously considered as a key empowering influence for productivity in supply chains. A few explore Endeavour have added to the field of IT for SSCM. The examination recognizes explore shortages just as an absence of logical talk utilizing exact methods and an absence of examinations on the social maintainability. Moreover, potential points for further explore were determined by contrasting the overview's outcomes with the ebb and flow inquire about on IT for 'general' SCM following the examination of 631 articles. Six fields could be distinguished, to be specific yield/impacts of IT, machine correspondence and multi agents, inputs furthermore, IT-bolstered handling, ITempowered inter organizational trade, quantitative IT draws near and an area center.
\end{abstract}

KEYWORDS: SCM, Manufactures, Retailers, End-Users.

\section{INTRODUCTION}

Power in the supply chain permanently rested with manufactures focusing on workflow, distributions, inventory and transportation function at the firm level ${ }^{[1]}$.

In the past, the focus of scientific investigations in SCM was primarily placed on economic sustainability, usually due to profitability considerations $^{[5]}$.

Over the last two decades, however environmental or 'green' factors have become increasingly incorporated into analyses in all fields. This holds true for SCM, where environmental concerns have been of special significance ${ }^{[5]}$. Supply chain risk management can help organizations to monitor the expecting hazards and control possible risks and thus improve the efficiency of the supply chain. This approach can help to improve and build up business process, prevent potential problems, minimize loss of commercial enterprise, reduce costs and liability, protect the $\mathrm{SCM}^{[3]}$. This paper seeks to address the lack of a clear view of research at the intersection of IT and SSCM by combing three below mentioned fields and aims to deliver an updated perspective of how IT can be used to improve sustainability in supply chains illustrated in fig $1^{[5]}$.

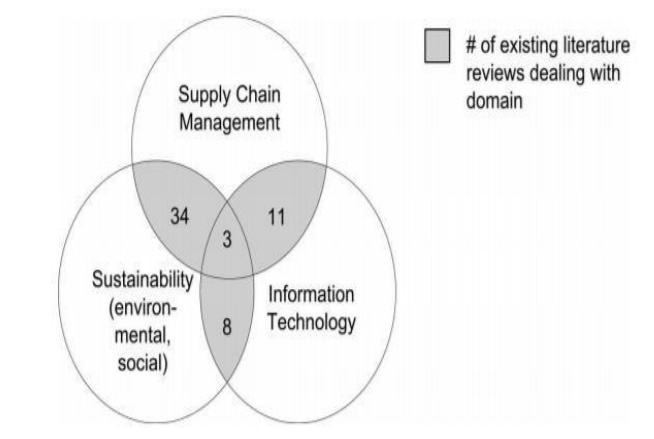

Figure 1. Overlap area of SCM, sustainability and IT including related literature reviews and number of papers analysed.

\section{METHODOLOGY}

(i) Management of the retail supply chai n:

Key priorities and practices RSCM research was based on a mix of qualitative and quantitative methods outline in Table 1

\begin{tabular}{|l|l|}
\hline Step & Analytical activity \\
\hline 1 & $\begin{array}{l}\text { Build the research questions that } \\
\text { open up }\end{array}$ \\
\hline 2 & $\begin{array}{l}\text { Start collecting information an } \\
\text { d initial coding }\end{array}$ \\
\hline
\end{tabular}




\begin{tabular}{|l|l|}
\hline 3 & $\begin{array}{l}\text { Set up initial codes in temporar } \\
\text { y categories }\end{array}$ \\
\hline 4 & $\begin{array}{l}\text { Collection of data aimed at exi } \\
\text { sting categories and the identifi } \\
\text { cation of new categories }\end{array}$ \\
\hline 5 & Filter codes into groups \\
\hline 6 & $\begin{array}{l}\text { Categories, dimensions and par } \\
\text { tnerships emerge }\end{array}$ \\
\hline 7 & Research \\
\hline 8 & Research analysis \\
\hline
\end{tabular}

\section{$T A B L E: 1$}

Survey participants included R-SCM executives and executives from industries that support the retail sector The ARS survey provided clarity on key issues in $\mathrm{R}-\mathrm{SCM}^{[1]}$.

\section{(ii) Sustainable Coffee Supply Chain Management}

Qualitative approach:

A qualitative methodology was used to analyse the current situation of sustainable behaviour and how sustainability certification practices are measured in terms of farming methods, social security, and farmers ' awareness of sustainable coffee production. You have experience of the current situation and the basic knowledge to respond to these clear and clean $^{[4][6]}$.

Following the research, it is plausible to conclude that the development of sustainable coffee in Buon Ma Thuot City in particular, and in Vietnam in general, offers many opportunities but still encounters some difficulties that need to be overcome $^{[6]}$. By means of Chi-square analysis, normal coffee to certified coffee. Researchers should provide them with guidance to help them manage the quality of their coffee farms. Finally, the logistic regression model is suggested to help government and sustainable coffee programs choose farmers with proper conditions in order to achieve more success ${ }^{[6]}$.

(iii) Pharmaceutical supply chain risk assessment in Iran using analytic hierarchy process (AHP) and simple additive weighting (SAW) methods

Methods:

The research was performed in 4 phases; risk identification through literature review, risk identification in Iranian pharmaceutical companies through experts interviews, risk analysis through a questionnaire and expert consultation using team analytical hierarchy (AHP) system and rating scale (RS) method and risk assessment of simple additive weighting (SAW) $\operatorname{process}^{[3]}$.

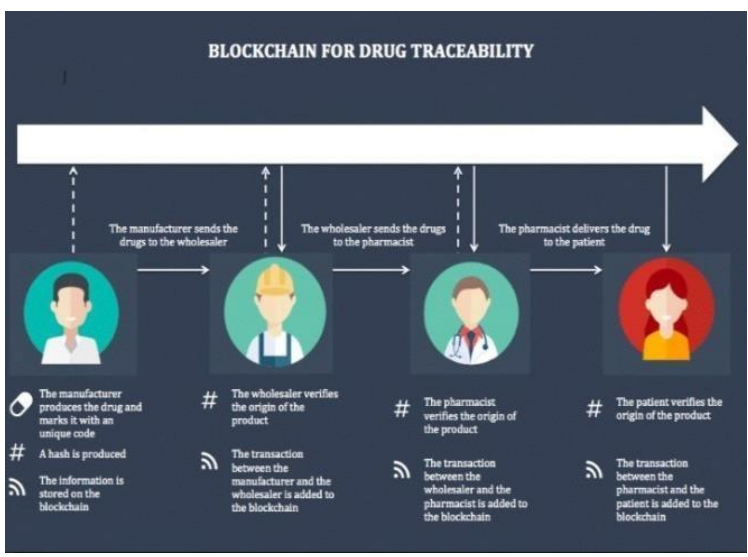

Fig: 2

(iv) The seafood supply chain from a fraudulent perspective

Methods:

The supply chain of seafood covers eight main stages from source to consumption. These include: origin, hatchery, nursery, growing, harvesting, manufacturing, business, and product operations. Both stages are slightly different for each of the finfish and mollusc supply chains. To eradicate the fraudulent opposition, it is important to know the types of fraud that the fraudster has ${ }^{[2]}$.

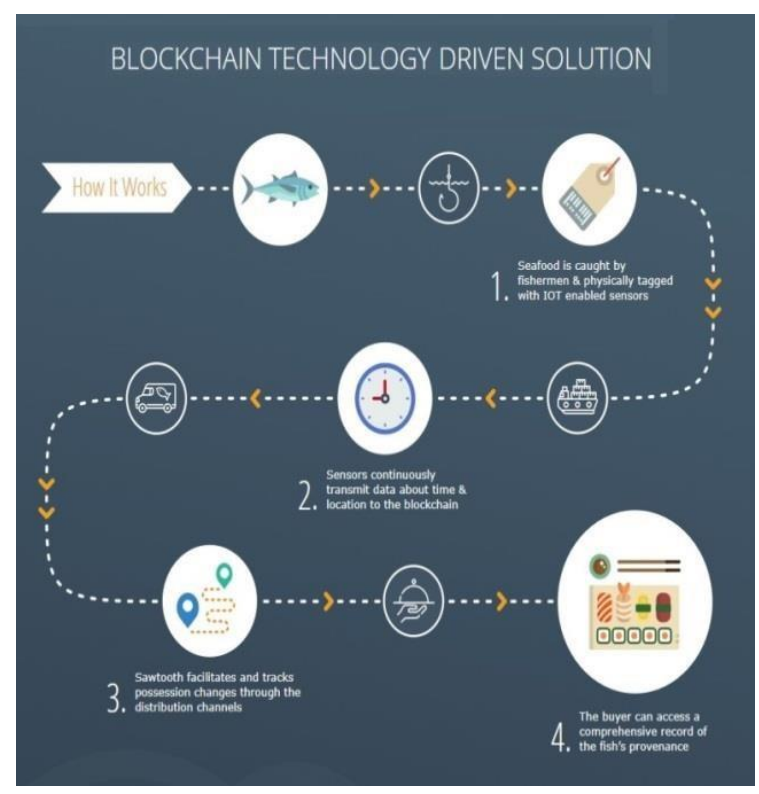

Fig:3

Spink and Moyer (2011) examine this opportunity using the criminal triangle consisting of the fraudster, 


\section{International Journal of Engineering Applied Sciences and Technology, 2020 \\ Vol. 4, Issue 10, ISSN No. 2455-2143, Pages 221-224 \\ Published Online February 2020 in IJEAST (http://www.ijeast.com)}

the victim, the guardian and the holes in the hurdle. To minimize opportunity, gathering evidence and information is essential to ensuring the successful creation and distribution of initiatives and assets shared within industry to ensure transparency and eventually accountability $^{[2]}$.

(v) The Role of Information Technology in Supply Chain Sustainability

Information technology is crucial for achieving economical and responsive offer chains. The aim of this paper is to produce a structured read of however IT will completely have an effect on SSCM. Many technologies exist these days that may assist you managing your provides and inventory. For producing firms to make substantial client bases, conversion of business processes has become a lot of a necessity than a value-add proposition. This has inflated the necessity for making a digital surroundings that seamlessly integrates and monitor the operations applied by varied entities within the offer chain ${ }^{[5]}$. Technological advancements currently alter businesses to make end-to- end offer chain solutions that speed up processes and avoid bottlenecks within the supply chain. offer chain management software package is intended to manage and enhance the exchange of data of across varied key supply chain partners to achieve such outcomes as just-in-time procural, reduction of inventory, increase of producing potency and to satisfy client desires in a very timely fashion ${ }^{[5][6]}$.

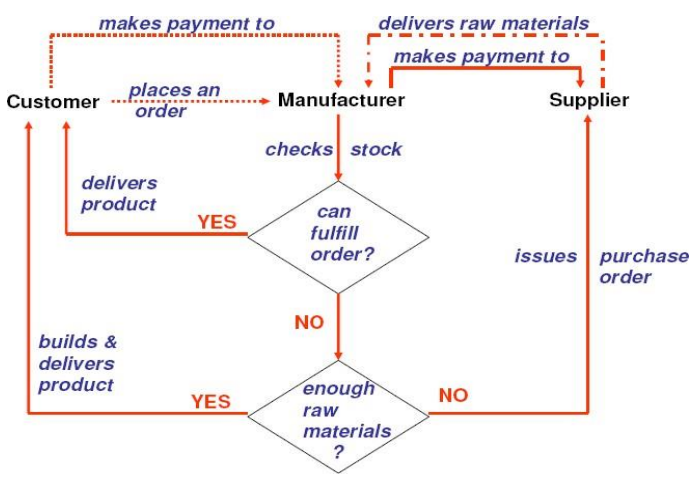

Fig:4- IT supply chain workflow

\section{Result Comparison:}

Taking into account recent economic conditions, the research results provide an exploratory summary of R-SCM activities The ARS survey provided clarity on key issues in R-SCM. The survey questions also helped us to quantify the classes that were qualitatively extracted ${ }^{[1]}$.

RQ1. Which problems catch R-SCM executives ' attention?
RQ2. How do retailers respond to these problems?

RQ3. What supply chain capabilities are required in the current retail environment to create a competitive advantage?

From an external perspective, retailers and R-SCM practices continue to influence the impact of the "Great Recession"[1].

Below table shows that the respondents of the survey still remain highly uncertain about the rate of recovery, while a small proportion are worried about problems that might interrupt the turnaround.

\begin{tabular}{|l|l|}
\hline Issue & $\begin{array}{l}\text { Percentage o } \\
\text { f Respondent }\end{array}$ \\
\hline $\begin{array}{l}\text { Achieving greater supply } \\
\text { chain agility }\end{array}$ & 38.9 \\
\hline $\begin{array}{l}\text { Maximizing asset utilizat } \\
\text { ion }\end{array}$ & 23.4 \\
\hline $\begin{array}{l}\text { Increasing supply chain } \\
\text { visibility }\end{array}$ & 15.6 \\
\hline $\begin{array}{l}\text { Enhancing internal goal } \\
\text { alignment }\end{array}$ & 11.7 \\
\hline
\end{tabular}

TABLE 2: Economic Concerns

\begin{tabular}{|l|l|}
\hline Issue & $\begin{array}{l}\text { Percentage of } \\
\text { respondents }\end{array}$ \\
\hline $\begin{array}{l}\text { Speed of economi } \\
\text { c recovery }\end{array}$ & 80.5 \\
\hline Tax increases & 7.3 \\
\hline $\begin{array}{l}\text { Consumer credit } \\
\text { availability }\end{array}$ & 7.3 \\
\hline
\end{tabular}

TABLE 3: Retailers Primary Goal

\section{Key Features:}

Administration of the supply chain may reduce the cost of getting supplies. Organizations reduce the sourcing risks of locating vendors, negotiating terms or issuing actual purchase orders by implementing deals to supply chain representatives.

\section{Responsiveness:}

Communication between participants is a function of management of the supply chain. Through holding vendors aware of demand changes, the lead company can make sure it gets the right level of supply. Information on demand enables suppliers to increase or reduce their capacity efficiently, eliminating the risk of waste or delivery delays.

\section{Access:}

A key benefit of supply chain management is 


\section{International Journal of Engineering Applied Sciences and Technology, 2020 \\ Vol. 4, Issue 10, ISSN No. 2455-2143, Pages 221-224 \\ Published Online February 2020 in IJEAST (http://www.ijeast.com)}

having access to necessary raw materials, products, suppliers and services. Instead of working ad hoc with manufacturers, businesses are establishing long-term procurement relationships so that they can be assured that they will get the products they need to operate their operations. Securing access to critical components or limited raw materials is particularly important.

\section{Advantages: INCREASED AND COLLABORATION
BETWEEN SUPPLY CHAIN PARTNERS}

Through allowing IT to exchange information in real time, manufacturers will enhance interaction with their main partners. Manufacturers can also monitor supply chain operations with insight into manufacturer end and distributor processes. Such information can help the manufacturers in making more informed decisions and better forecast future demand.

\section{CONCLUSION}

Given all the considerations in the preceding articles, they will develop a SCM technology which would usually aim to centrally manage or connect the manufacture, shipping and delivery of a commodity in small-scale industries. This would help small-scale factories to minimize excess costs and supply products to consumers more quickly.

\section{REFERENCES}

[1] S. Wesley, J. Gibson, C. Clifford Defee, Randall Department of Marketing and Logistics, College of Business, University of North Texas, Denton, Texas, USA Brian Department of Supply Chain Management, College of Business, Auburn University, Auburn, Alabama, USA, and. Williams Department of Supply Chain Management, Sam M. Walton College of Business, University of Arkansas, Fayetteville, Arkansas, USA(2011)- Retail supply chain management: key priorities and practices. The International Journal of Logistics Management Vol. 22 No. 3(pp. 390-402).

[2] Michaela Fox \& Mike Mitchell \& Moira Dean \& Christopher Elliott \& Katrina Campbell(2018) The seafood supply chain from a fraudulent perspective. Food Security 10:939-963

[3] Mona Jaberidoost, Laya Olfat, Alireza Hosseini, Abbas Kebriaeezadeh, Mohammad Abdollahi, Mahdi Alaeddini and Rassoul Dinarvand (2015) Pharmaceutical supply chain risk assessment in Iran using analytic hierarchy process (AHP) and simple additive weighting (SAW) methods. Jaberidoost et al. Journal of Pharmaceutical Policy and Practice 8:9 DOI 10.1186/s40545-015-0029-3.

[4] Craig R. Carter Arizona State University, Tempe, Arizona, USA, and P. Liane Easton Center for Logistics Management, University of Nevada, Reno, Nevada, USA (2011) - Sustainable supply chain management: evolution and future directions. International Journal of Physical Distribution \& Logistics Management Vol. 41 No. 1(pp. 46-62).

[5] Andreas Thöni and A Min Tjoa Institute of Software Technology and Interactive Systems, Vienna University of Technology, Vienna, Austria (2017) Information technology for sustainable supply chain management, Enterprise Information System, Vol. 11, No. 6, 828-858.

[6] Giang N. T. Nguyen and Tapan Sarker (2018) Sustainable coffee supply chain management: a case study in Buon Me Thuot City, Daklak, Vietnam, Nguyen and Sarker International Journal of Corporate Social Responsibility.

[7] Andrea Genovese, Adolf A. Acquaye, Alejandro Figueroa, S.C. Lenny Koh (2015) Sustainable supply chain management and the transition towards a circular economy: Evidence and some application-Logistics and Supply Chain Management Research Centre, Management School, University of Sheffield, Sheffield, UK .

[8] Christoph H. Glock, Taebok Kim- Container management in a single-vendor (2014) - multiplebuyer supply chain, Copy Right at Springer-Verlag Berlin Heidelberg.

[9] Esfahbodi, Ali, Zhang, Yufeng, Watson, Glyn, Zhang, Tao (2016) - Governance pressures and performance outcomes of sustainable supply chain management, An empirical analysis of UK manufacturing industry, Journal of Cleaner Production.

[10] Nir Kshetri (2018) - Blockchain's roles in meeting key supply chain management objectives, The University of North Carolina, Greensboro, United States, International Journal of Information Management. 